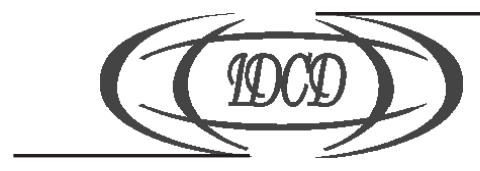

УДК 331

\title{
Д.П. МЕЛЬНИЧУК,
}

канд. екон. наук, доц., докторант

Інституту демографії та соціальних

досліджень ім. М.В. Птухи НАНУ

E-mail: meln_dp@mail.ru

\section{«ЛЮДСЬКИЙ КАПІТАЛ»: ТЕОРЕТИЧНІ АСПЕКТИ ДОСЛІДЖЕННЯ}

У статті досліджено проблеми змісту та узгодженості понятійного апарату економіки праці. Обгрунтовано, що термінологічні непорозуміння вкрай негативно впливають на перспективи розвитку соціально-трудової сфери. Проаналізовано сутність базових категорій науки про працю, що дало змогу визначити та охарактеризувати принципові відмінності між економічними категоріями «трудовий потенціал» та «людський капітал».

Ключові слова: термінологія, економіка праці, трудовий потенціал, людський капітал, рівень та якість життя населення.

Постановка проблеми. Термінологічна плутанина, що дедалі більше поглинає сферу економіки праці, перешкоджає розробці та реалізації дієвих заходів, спрямованих на прискорений розвиток та ефективне використання людського капіталу. На жаль, не всі вчені переймаються проблемою чистоти мовного апарату економічної науки. Та саме від якості останнього залежить як об’єктивність теоретичних суджень, так і результативність практичних рекомендацій. У такому контексті заслуговують на увагу висновки Т. Кір'ян та Ю. Кулікова, які зазначають, що незважаючи на численні «...прогресивні публікації вітчизняних авторів, ще продовжуються історичні екскурси у витоки людського капіталу». В окремих із них, - зауважують українські вчені, - дослідники надають неабиякого значення ірраціональним розсудам з приводу термінології, у «...якій ідентифікується людина та їі здібності» [1, с. 26]. I хоча автор не схильний до подібного оптимізму щодо масштабів «прогресивних публікацій», складно не погодитись з думкою про надмірну кількість вкрай неоднозначних міркувань, якими переповнені сторінки вітчизняної та перекладної економічної літератури.

Термінологічні непорозуміння негативно впливають на результативність пропозицій, сформованих за підсумками наукових досліджень. I, передусім, внаслідок того, що зайва неоднозначність у трактуваннях зводить нанівець усі спроби встановлення раціональних взаємозв’язків між економічними категоріями, що, в підсумку, 
позбавляє логіки заходи, спрямовані на розв'язання актуальних проблем соціальнотрудової сфери.

Аналіз останніх досліджень та публікацій. Дослідження наукових праць на предмет узгодженості понятійного апарату дає можливість сформулювати такі висновки:

- безсистемне та необгрунтоване застосування тих чи інших економічних категорій у процесі дослідження соціально-трудової сфери є доволі поширеним явищем в Україні та інших державах пострадянського простору;

- попри те, що наука про працю оперує доволі-таки скромним числом фундаментальних понять, плутанина у їх розумінні зростає із року в рік зі швидкістю геометричної прогресії;

- нерідко різні вчені застосовують діаметрально протилежні трактування одних і тих самих економічних термінів, які можуть досить комфортно співіснувати на сторінках одного й того ж наукового видання;

- подекуди, автори впроваджують та довільно користуються власними термінологічними симбіозами за відсутності належної уваги до обгрунтування їх змісту та необхідності застосування.

Останнє певною мірою обумовлюється впливом перекладів закордонних видань, сторінки яких майорять радикальними для вітчизняної наукової думки термінологічними рядами. Ці та інші роботи могли б сприяти оновленню методології економіки праці або утвердженню іiі існуючих позицій, але насправді застосування термінів на кшталт «економіка персоналу», «потенціал робочої сили», «потенціал трудових ресурсів», «потенціал людського фактора», «людський ресурсний капітал» лише «підвищує градус» і без того запеклих науково-теоретичних суперечок. У переважній більшості випадків поява та застосування подібних термінологічних новацій є безперспективним наслідком неосвіченості та байдужості, яку виявляють деякі зарубіжні та вітчизняні автори, редактори та перекладачі стосовно змісту понятійного апарату економічної науки. 3 другого боку, викликають значні занепокоєння й масштаби необгрунтованого та безсистемного застосування економічних категорій безпосередньо вітчизняними дослідниками, коли апелювати до «складностей перекладу» вже неможливо.

Частково така ситуація пояснюється термінологічною необізнаністю, а частково тим, що «...окремі терміни та поняття, які колись мали під собою цілком об'єктивну основу, у наш час втрачають своє початкове смислове значення» [2, с. 33]. У тому числі, відкритими залишаються деякі непрості запитання, що стосуються відповідності окремих економічних категорій новим реаліям суспільно-політичної та соціально-економічної дійсності, адже зміна епох не може не позначитись на складі термінологічного апарату. За словами Ю. Попова, у світі, який швидко змінюється, одні поняття «..зникають, інші наповнюються новим змістом, треті відстоюють право на визнання» [2, с. 37]. На думку В. Мандибури, це, передусім, стосується тих узагальнюючих понять, які найбільше розкривають зміст об’єктивних соціальноекономічних відносин: «капітал», «робоча сила», «трудовий потенціал», «людський капітал» [3, с. 26].

Мета дослідження визначається необхідністю уточнення наукової термінології економіки праці, а також вимогою іiї змістовного розширення відповідно до сучасних потреб господарської практики. 
Виклад основного матеріалу. Термінологія - невід’ємний атрибут будь-якої науки. Важливо спочатку встановити, що мається на увазі під тим чи іншим терміном, і лише потім оперувати ним. Уточнюючи термінологію, необхідно розуміти, що вона є базовим інструментом формулювання наукових гіпотез, їх доведення або спростування. Понятійний апарат науки можна розглядати як універсальну систему мовних означень. Це й же універсальний, проте специфічний, мовний апарат застосовують під час розробки пропозицій, спрямованих на покращення якостей об'єктів чи оптимізацію певних процесів. Зрозуміло, що відповідні терміни повинні трактуватись однозначно, без зайвої полеміки щодо їх суті. В іншому випадку формуватиметься похідне дослідницьке коло, коли замість розв'язання прикладних завдань, вчені знову і знову сперечатимуться про мовний інструментарій.

Примітно, що переважна більшість монографічних праць та навчальних посібників традиційно починається з аналізу економічних категорій. Але результати відповідних узагальнень, як правило, дублюють уже відомі і, подекуди, вкрай неоднозначні трактування одних і тих самих термінів: «робоча сила», «трудовий потенціал», «трудові ресурси», «персонал». На жаль, у багатьох випадках це призводить до надмірного захаращення понятійного апарату науки про працю. Подібне явище властиве не лише вітчизняній, а й зарубіжній науці. У роботах П. Самуельсона воно отримало назву «тиранії слів». Нобелівський лауреат писав: «У соціальних науках необхідно особливо остерігатися «тиранії слів». Світ надто складний і без того, щоб у нього привносили нову плутанину та незрозумілості, пов'язані з тим, що, по-перше, два різних слова через незнання використовуються для позначення одного й того ж предмета, i, по-друге, одне й те ж слово вживається стосовно двох абсолютно різних явищ» [4, с. 11]. Опускаючи міркування та деякі аргументи щодо правомірності тих чи інших трактувань фундаментальних категорій науки про працю, що за обсягом не могли бути включеними до тексту представленої статті, зупинимося на основних висновках, сформульованих автором.

Таке узагальнення варто розпочати з того, що своєю життєдіяльністю людина завдячує різноманітним психофізіологічним процесам. Вони забезпечують функціонування усіх фізіологічних та психосоматичних систем організму та дають змогу індивіду певним чином діяти в оточуючому середовищі. Процес, за якого homo sapiens діє задля досягнення своїх цілей, дістав назву «діяльність». Цей процес забезпечується силами організму. Якщо йдеться про трудову діяльність, то вважаємо цілком логічним йменувати відповідну силу робочою. Сили організму детермінуються життєздатністю людини, робоча сила - працездатністю. Те й інше визначається здоров'ям індивіда.

Завдяки використанню сил організму відбувається процес набуття знань та трудових навичок. Саме ці складові людського інтелекту й формуватимуть основу таких феноменів, як трудовий потенціал та людський капітал. Але важливо, що в процесі праці робоча сила оперуватиме не тим, і не іншим. I саме у цій точці теоретичних міркувань, як правило, зароджується плутанина, що вже багато десятиліть деформує понятійний апарат економіки праці. Так - не трудовий потенціал, іне людський капітал використовує людина в процесі праці, а лише таки своє тіло, знання, навички й вміння, які є певними «згустками» інформації та містяться у їі мозку. Натомість, як трудовий потенціал, так ілюдський капітал, є лише теоретико-прикладними о́бразами, уявними конструкціями, які сприяють дослідженню, осягненню та усвідомленню специфіки соціально-економічних закономірностей у тому чи іншому розрізі проблеми. 
Розвиток психофізіологічної компоненти, яка є відображенням здатності організму людини генерувати силу, що отримала назву «робочої», є вихідним пунктом формування трудового потенціалу. Тільки у тому випадку, коли проблему працездатності розв'язано успішно, суспільство може замислитись про наявність трудового потенціалу у повній мірі, що означатиме замислитись над здатністю розв'язувати господарські завдання на тому чи іншому рівні економічної системи. Відповідно, трудовий потенціал є узагальненою характеристикою суспільства, трудового колективу, окремої людини, що виражає спроможність останніх розв'язувати широкий спектр економічних завдань за умови наявності необхідних технологій, а також матеріальних та фінансових ресурсів. Натомість, економічна категорія «людський капітал» має іншу природу та призначення. Це категорія політекономічного змісту, адже свідчить про характер та закономірності розподілу суспільного продукту між різними верствами населення, про статус та роль окремих соціальних прошарків, перспективи покращення рівня та якості життя працівників ma їхніх сімей. Теоретично, про наявність людського капіталу можна говорити у тому разі, коли розмір трудових доходів працюючих перевершує вартість залученої робочої сили з урахуванням витрат, понесених внаслідок набуття загальної та професійної освіти. При цьому змінюється й сам підхід до розуміння природи заробітку працівника, у структурі якого з'являється така складова, як «відсоток» на людський капітал.

За подібного розуміння проблеми, між проаналізованими категоріями можна встановити чіткий взаємозв'язок: наявність розвиненого трудового потенціалу $\epsilon$ передумовою виникнення феномену людського капіталу (рис. 1). Але, якщо у площині проблематики «трудового потенціалу» знання та інші продуктивні спроможності людини становлять інтерес у розрізі запитання про можливість реалізації конкретних економічних цілей, то у площині «людського капіталу» - у розрізі можливості приносити дохід своєму власнику. Тут же міститься й відповідь на запитання, чому автор не підтримує думку про те, що людський капітал є реалізованою частиною трудового потенціалу.

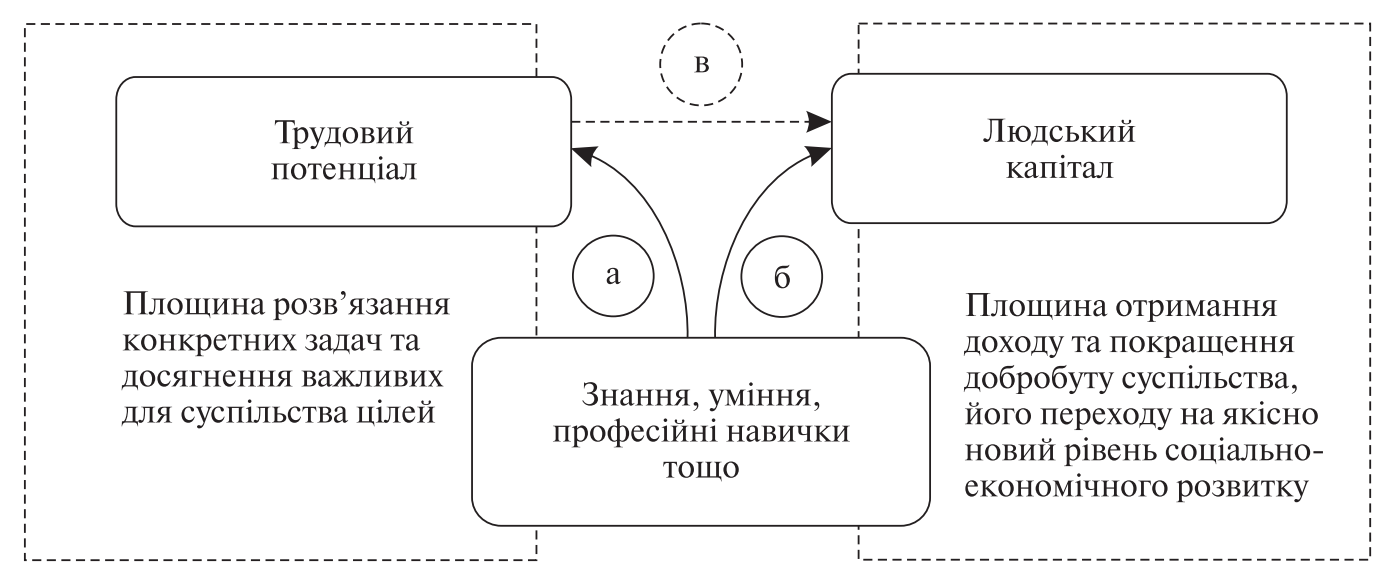

Рuc. 1. Трудовий потенціал як передумова застосування продуктивних спроможностей людини в якості капіталу 
Так, у вітчизняній економічній термінології поняття «трудовий потенціал» 3'явилося ще у 70-х роках минулого століття. Воно набуло конкретної ролі та змісту. Саме аналізуючи параметри трудового потенціалу вчені намагалися уточнити перспективи реалізації поставлених перед суспільством цілей. I таки цілі досягалися, а трудовий потенціал - реалізовувався. Та чи набували відповідні знання й професійні навички ознак капіталу? Непоодиноких, репрезентативних підтверджень такого перебігу подій немає. I, як зазначає О. Грішнова, принципова відмінність, що накладає певні обмеження на сферу застосування понять «трудовий потенціал» $\mathrm{i}$ «людський капітал» - середовище їх виникнення, адже людський капітал - поняття виключно ринкової економіки, а категорія трудовий потенціал використовувалася у період командно-адміністративної системи [5, с. 14]. Іншими словами, в умовах, коли розміри заробітних плат визначалися не на ринковій, а на адміністративно-плановій основі, говорити про знання як капітал не доводилося. Можна навести й безліч інших прикладів 3 історії людської цивілізації, коли те, що пізніше було назване трудовим потенціалом, з об'єктивних причин не могло принести дохід своєму власнику - реалізуючись, але не набуваючи ознак капіталу. І якщо ми ігноруватимемо цей факт, то проблематика останнього знову-таки втратить свою якісну специфіку, а відтак, і сенс застосування в процесі дослідження еволюції взаємовідносин у соціально-трудовій сфері.

У такому контексті важливо, що у соціумах, які досягли високого рівня розвитку, товаром на ринку праці виступає саме праця, а не робоча сила. Останнє, на переконання деяких вчених, $є$ сумнівним, адже не відповідає визначенню робочої сили з позицій трудової теорії вартості. Інші - навпаки, вступають 3 цього приводу у запальну суперечку з прибічниками позиції К. Маркса. Наприклад, О. Рофе відстоює думку про помилковість висновків класика політичної економії щодо того, що на ринку продається не праця, а робоча сила, і що заробітна плата - це не вартість праці, а вартість робочої сили [6, с. 98]. «Насправді, робочу силу як спроможність до праці неможливо продати, так як вона невіддільна від свого носія. Але продається те, за що працівник отримує заробітну плату. А отримує він її за працю, а не за свої спроможності», - переконує російський вчений [7, с. 16]. Разом з тим К. Маркс таки мав рацію, і кожна зі сторін цієї науково-теоретичної дискусії дещо помиляється. Але у чому саме?

У попередніх роботах автора було неодноразово відмічено той факт, що трудова теорія вартості відповідала реаліям саме свого часу. Було також аргументовано, що «...об’єктивність виробничих відносин проявляється у то́му, що люди не можуть здійнятися над рівнем власного розвитку, спроможностей та потреб, які визначені наперед об'єктивними умовами їх існування», i що саме останні детермінують «...економічні форми, завдяки яким людина може впливати на економіку» [8, с. 22]. Наприкінці XIX століття усе різноманіття життя працівників, як правило, обмежувалося виконанням виключно виробничих функцій, а їх дозвілля не переслідувало навіть елементарних екзистенціональних цілей, призначаючись для гігієнічних процедур та відпочинку задля відновлення працездатності. За таких умов, майже усі витрати працівників справді забезпечували відтворення саме робочої сили та визначали ï вартість. Так - не робоча сила, а праця є товаром на відповідному ринку, але важливо, що ціна подібного товару за часів К. Маркса якраз і обумовлювалася вартістю робочої сили працівників, життя яких не перевищувало межу «...голодного мінімуму» [9, с. 228-229]. За свідченням українського вченого А. Коровського, «...людина й робоча сила майже збігаються у рабовласницькому суспільстві. Незначною $є$ ця різниця і для феодального суспільства та перших періодів розвитку капіталістичного 
виробництва (курсив - авт.)» [10, с. 7]. Іншими словами, за відсутності істотних аргументів та надлишку тих, хто був готовий за безцінь працювати по чотирнадцять годин на добу, у капіталіста просто не було підстав змінювати принципи обчислення розміру трудової винагороди, адже не альтруїзм, а прагматичний розрахунок був і залишається головним «козирем» виробничо-комерційної діяльності.

Отже, річ не у тому, що трудова теорія вартості не відповідала дійсності - у переважній більшості випадків вона була цілком правдоподібною моделлю взаємодії праці та капіталу у період зародження та розвитку капіталізму. Та «...на відміну від математики, в економіці не усі закони ідеальні, а тому деякі з них можуть бути використані лише на певних етапах суспільного розвитку» [11, с. 41]. Трудова теорія вартості в інтерпретації К. Маркса виявилася історично неперспективною для застосування в епоху надмірного ускладнення технологічних операцій, прискореного розвитку знань, а відтак, і безпрецедентного посилення переговорної позиції найманих працівників.

Посилення переговорної позиції працівників позначилось на тому, що сьогодні думки класика політичної економії стали невідповідними суспільно-політичній та соціально-економічній дійсності, але є багато доказів того, що тоді - наприкінці XIX ст. - саме так і відбувалося: робітник був загнаний у «глухий кут», поставлений в умови, за яких вартість робочої сили й визначала ціну його праці, яка була еквівалентом вартості тих благ, що були необхідні його сім’ї для життя, а йому самому для підтримки власного організму у працездатному стані. I саме розуміння иього $\epsilon$ передумовою справді наукового опрацювання проблеми людського капіталу, поява якого змінила колишню формулу обчислення заробітків працюючих, здолавши ототожснення вартості робочої сили з ціною праці, привнісши у структуру останньої таку складову, як «відсоток» на людський капітал. За словами Т. Шульца, «...зростання інвестицій у людину суттєво змінює структуру заробітної плати; основна її частина - це дохід від людського капіталу» [12, с. 505].

Натомість, на думку О. Рофе, поняття людського капіталу - лише метафора: «...використане Т. Шульцем, Г. Беккером та іншими дослідниками поняття «людський капітал» є суто інакомовним, метафорою і не більше того» [14, с. 21]. «Це, безумовно, метафора, тобто використання слова у переносному сенсі», - стверджує російський вчений і в інших публікаціях. Підтвердженням тому, нібито, є той факт, що подібний «капітал» важко перевести у грошову форму [7, с. 19; 13, с. 21]. Метафори, - наполягає він, - прийоми (фігури мови), які широко використовуються у художній літературі. «Вони, можливо, доречні і в наукових публікаціях. Але виражати метафорами економічні категорії уявляється непотрібним та небезпечним, так як це може призвести (і вже призвело у випадку різноманіття поняття «капітал») до заплутування читача, до розмивання точного змісту» [14, с. 22]. На думку О. Рофе: «...для економічних зіставлень та розрахунків мають значення лише ті економічні категорії, які можуть бути представлені кількісними економічними показниками, а людський капітал такого показника (вимірника, індикатора) не має. Саме цим «людський» та інші вигадані «капітали» й відрізняються від фінансового, грошового капіталу, що дає підстави сумніватися у правомірності застосування слова «капітал» до всього того, що не має відношення до працюючих грошей» [7, с. 18].

Та подібні коментарі не витримують жодної критики. Вони є неминучим наслідком вивчення проблематики «людського капіталу» поза контекстом тих суспільно-політичних, техніко-технологічних, економічних та соціальних змін, якими ознаменувалося минуле століття, та які призвели до появи нових форм капіталу. Справді - безпідставне 
приписування знанням властивостей капіталу - неправомірне та неприпустиме явище! I тут не можна не погодитися із зауваженням О. Рофе: «Знання... - це свого роду капітал, накопичення якого може принести дохід (але може і не принести - як тоді бути з «капіталом»?»)» [13, с. 21]. Але у тому то й справа, що йдеться про набуття таких знань, створення таких умов для їх застосування, за яких останні зможуть виступити підставою для перегляду самого приниипу розподілу доданої вартості, набуваючи тим самим ознак капіталу не у переносному, метафоричному, а у прямому сенсі. Для обгрунтування цієї ідеї автор і звертався у своїх роботах до розгорнутого аналізу «Капіталу» K. Маркса, наражаючи себе на критику опонентів, адже саме за часів фундатора трудової теорії вартості існувала у чистому вигляді система взаємовідносин між капіталом та найманою працею, за якої ціна останньої й дорівнювала вартості робочої сили. І саме на фоні особливостей тогочасної моделі соціально-трудових відносин проступають та стають більш виразними контури економічних закономірностей нового, сучасного, постіндустріального світу, у якому можливість застосування знань та різноманітних продуктивних спроможностей людини в якості капіталу є запорукою як підвищення рівня, так і покращення якості життя всіх верств населення.

Тут же спростуємо сарказм російського професора й щодо відповіді на запитання «...де більше людського капіталу - у науково-дослідній установі чи у торговій фірмі за однакової чисельності персоналу?». «За ціною праці (а це, як вважають деякі вчені, один із виразів людського капіталу) торгова фірма у Росії залишить науково-дослідну організацію далеко позаду. Якщо порівнювати оплату праці у державних НДІ чи ВНЗ з оплатою праці працівників вітчизняних банків, то різниця, знову-таки, буде на користь останніх» [14, с. 21]. Але насправді, для того щоб знання набули форму капіталу, позначившись на заробітній платі, мало бути вченим чи викладачем ВНЗ. Знання як знання і знання як капітал - різні речі. I проблематика людського капіталу - це проблематика не стільки накопичення знань, скільки - застосування, а точні ше - умов та результативності застосування. Звісно, глибокі та сучасні знання мають більше шансів набути ознак капіталу, забезпечивши дохід своєму власнику, але цього замало: навіть прогресивні знання можуть так і залишитися всього лише знаннями. Для того щоб останні виступили у ролі капіталу, вони мають бути застосовані з метою отримання доходу. А якщо йдеться про науку, то відповідні знання мають бути втілені у конкретних дохідних проектах та у кінцевих продуктах, які мають високу ринкову вартість.

Отже, немає ніякого парадоксу, і ніяким чином описана ситуація не може поставити під сумнів правомірність теорії людського капіталу. Вітчизняний вчений, яким би обізнаним він не був, яким би корисним не був для суспільства його досвід, так і залишатиметься лише носієм знань, а не людського капіталу, доти, доки ці знання не будуть застосовані ним самим більш продуктивно, ніж під час запеклих наукових дискусій чи написання статей - не кажучи вже про тих «вчених», праця яких зводиться до репродукування і без них відомих істин. Крім того, не варто забувати й про фактор «умов», адже далеко не все залежить від доброї волі носія прогресивних знань та практичних навичок, тим паче в умовах країн, які розвиваються, де авансцена економічних взаємовідносин, як і багато століть тому, належить лихварському, купецькому $і$ торговому, а не іншим, більш прогресивним формам капіталу - промисловому, соціальному та людському.

Висновки та перспективи подальших досліджень. За висновками американського економіста і соціолога Дж. Коулмана, якщо фізичний капітал цілком відчутний, 
будучи втіленим в очевидних матеріальних формах, то людський капітал менш помітний. Він виявляється через навички та знання, що набуті індивідом. Так само, як фізичний капітал створюється змінами у матеріалах, з яких виготовляються засоби виробництва, - зазначав професор Університету Чікаго, - людський капітал створюється шляхом внутрішньої трансформації самих індивідів, що дає їм можливість діяти по-іншому [15, с. 126]. Важливо, що вчений не стверджував, нібито людським капіталом і є самі знання та навички. Згідно з його позицією, якої дотримується й автор, знання та навички людини є лише певним субстратом, що акумулює у собі та завдяки якому виявляється цей різновид капіталу. Зважаючи на це, спадає на думку, що людський капітал як економічну категорію правомірно та необхідно трактувати у розрізі проблематик двох взаємообумовлених площин: інвестиційної, що відображатиме закономірності формування досліджуваного активу, та результативної, яка міститиме у собі відповіді на питання про наслідки його практичного застосування.

Чим аргументується такий підхід? Він аргументується вимогою цілісного розуміння проблеми капіталу як економічного феномену, чого так бракує сучасним науковим поглядам і дослідженням, у яких для простоти отримання шуканих, і досить часто наперед визначених, висновків ігнорується той факт, що капіталом є економічний актив, який не лише формується в результаті інвестицій - такої постановки проблеми достатньо тільки для ресурсного підходу - а й безпосередньо забезпечує отримання деякого доходу своєму власнику. Самі по собі - ізольовано одна від одної - жодна з цих площин не забезпечать об'єктивного уявлення про капітал як феномен економічної дійсності. Відповідно, авторська позиція полягає у тому, що людський капітал є економічним активом, що акумулюється в результаті фінансових та соціальних інвестицій та виявляється в процесі доцільного застосування системи продуктивних спроможностей індивіда. Водночас людським капіталом необхідно визнати й економічний феномен форму вираження продуктивних спроможностей людини, яка актуалізується за певних умов господарювання і засвідчує своєю наявністю трансформацію звичних закономірностей розподілу доданої вартості у системі соціально-економічних відносин, спонукаючи тим самим сім'ї, суб’єктів господарювання та державу у цілому до перегляду та зміни звичних інвестиційних намірів та пріоритетів.

Шляхом спрощення та поєднання наведених трактувань можна дійти висновку, що під людським капіталом правомірно розуміти економічний актив, щзо формується в результаті різноманітних інвестицій шляхом набуття знань та доцільної видозміни продуктивних спроможсностей індивіда (трудового колективу, суспільства в цілому) та є формою представлення останніх в ході трудової діяльності, яка забезпечує певний дохід учасникам інвестиційно-виробничого процесу.

\section{ЛІТЕРАТУРА}

1. Кір'ян T., Куліков Ю. Нове в теорії, методології та практиці людського капіталу / Т. Кір'ян, Ю. Куліков // Україна: аспекти праці. - 2008. - №4. - С. 26-31.

2. Попов Ю.Н. Изменяющийся мир и наши представления о нем / Ю.Н. Попов // Труд и социальные отношения. - 2009. - № 12. - С. 32-37.

3. Мандибура В. «Людський капітал»: об’єктивна економічна реальність чи ідеологема? / В. Мандибура // Україна: аспекти праці. - 2009. - №2. - С. 26-33.

4. Самуэльсон П. Экономика. Т. І. - М.: НПО «АЛГОН», ВНИИСИ, 1992. - 333 с.

5. Грішнова О.А. Людський капітал: формування в системі освіти і професійної підготовки / О.А. Грішнова /. - К.: Т-во «Знання», 2001. - 254 с. 
6. Рофе А.И. Экономика труда: учебник / А.И. Рофе. - М.: КНОРУС, 2010. - 400 с.

7. Рофе А.И. Еще раз о рабочей силе и человеческом капитале / А.И. Рофе // Труд и социальные отношения. - 2010. - №.3. - С. 13-19.

8. Мысляева И.Н. Человеческий фактор: политэкономический аспект / И.Н. Мысляева /. - М.: Экономика, 1989. - 142 с.

9. Аникин А.В. Юность науки. Жизнь и идеи мыслителей-экономистов до Маркса. Изд. 2-е, доп. и переработ. / А.В.Аникин /. - М: Политиздат, 1975. - 384 с.

10. Коровський А.В. Еволюція людського фактора економіки та проблеми його формування: Монографія / А.В. Коровський /. - К.: КНЕУ, 2004. - 184 с.

11. Кязимов К.Г. Профессиональная компетентность - основной критерий оценки человеческого капитала / К.Г. Кязимов // Труд и социальные отношения. - 2010. - №2. - С. 41-46.

12. Одегов Ю.Г., Руденко Г.Г., Бабынина Л.С. Экономика труда: Учебник. В 2 т. Т.1. - М.: Издательство «Альфа-прес», 2007. - 760 с.

13. Рофе А.И. Может ли капитал быть человеческим, а поведение организационным? / А.И. Рофе // Труд и социальные отношения. - 2009. - №. 10. - С. 18-22.

14. Рофе А.И. Может ли капитал быть человеческим, а поведение организационным (окончание)? / А.И. Рофе // Труд и социальные отношения. - 2009. - №.11 - С. 19-25.

15. Коулман Дж. Капитал социальный и человеческий / Дж. Коулман // Общественные науки и современность. - 2001. - №3. - С. 122-139.

Стаття надійшла до редакції журналу 23.05.2013

\section{Д.П. Мельничук}

\section{«ЧЕЛОВЕЧЕСКИЙ КАПИТАЛ»: ТЕОРЕТИЧНІ АСПЕКТИ ДОСЛІДЖЕННЯ}

Основное внимание статьи сосредоточено в плоскости содержания и согласованности понятийного аппарата экономики труда, актуальность чего обуславливается тем, что терминологические разногласия крайне негативно влияют на перспективы развития социально-трудовой сферы. Автором установлено, что сегодня в науке о труде превалирует ситуация, при которой базовые термины и понятия трактуются настолько широко, что, фактически, становятся синонимами, теряя при этом свою терминологическую идентичность. Это приводит к тому, что содержательные, на первый взгляд, выводы и умозаключения, на поверку оказываются настолько общими и двусмысленными, что их практическое использование становиться весьма затруднительным. При этом смысл многих научных работ не выходит за рамки обоснования важности или приоритетности тех или иных изменений при полном игнорировании того, каким образом эти изменения могут быть достигнуты в условиях реальной экономической среды. И это не удивительно, так как неуместное, противоречащее результатам эволюции общественно-экономических отношений, своевольное, ничем не обоснованное использование и взаимное отождествление экономических категорий в принципе заводит в тупик и теоретическую науку, и практические преобразования. Прежде всего, это касается такой политэкономической категории, как капитал, которая отображает не только инвестиционную природу неких активов, но и переводит дискуссию в плоскость их доходности, непосредственно затрагивая вопросы рычагов и справедливости распределения прибавочной стоимости, что, несомненно, влияет и на систему общественных взаимоотношений во всем многообразии ее проявлений. Вне этого контекста анализ проблематики как человеческого капитала, так и капитала вообще теряет всякий смысл.

С целью обоснования высказанных суждений, в статье представлен анализ основных категорий экономики труда, в том числе, исследованы различия между экономическими категориями «человеческий капитал» и «трудовой потенциал». Аргументировано, что трудовой потенциал правомерно толковать как обобщенную характеристику общества, трудового коллектива, отдельного человека, которая выражает их способность решать широкий спектр экономических задач при наличии необходимых технологий, а также материальных и финансовых ресурсов. Вместе с тем, согласно позиции автора, экономическая категория «человеческий капитал» имеет принципиально иную природу и предназначение. Эта категория касается закономерностей 
распределения общественного продукта, статуса и ролей отдельных социальных слоев, перспектив повышения уровня и улучшения качества их жизни.

В целом, в результате проведенного исследования автор приходит к выводу, что проблему человеческого капитала правомерно рассматривать в ракурсе двух взаимообусловленных плоскостей: инвестиционной, отражающей закономерности формирования исследуемого актива, и результативной, содержащей в себе ответы на вопрос о последствиях его практического применения. Соответственно, сформулирован вывод о том, что под человеческим капиталом необходимо понимать экономический актив, который формируется в результате различных инвестиций путем целесообразного видоизменения системы производительных способностей индивида (трудового коллектива, общества в целом) и является формой представления этих способностей в процессе трудовой деятельности, которая обеспечивает определенный доход участникам инвестиционнопроизводственного процесса.

Ключевые слова: терминология, экономика труда, трудовой потенциал, человеческий капитал, уровень и качество жизни населения.

\section{D.P. Melnichuk}

\section{«HUMAN CAPITAL»: THE THEORETICAL ASPECT OF THE STUDY}

Today in the science of labor the basic terms and concepts are being interpreted too broadly. They, in fact, become synonyms and lose terminological identity. This leads to apparently meaningful findings and conclusions proving to be too generalized. As a result, their application in practice becomes extremely difficult. Unfortunately, the meaning of many scientific papers does not go beyond the justification of importance or priority of any changes. At the same time a complete disregard for the way in which these changes can be achieved in the absence of real economic environment is observed. This is not surprising, since inappropriate, inconsistent, willful, unreasonable use, and identification of economic categories leads both theoretical science and practical transformations to a deadlock. And, above all, this concerns such economic category as capital. This category reflects not only the nature of certain investment assets, but also takes the discussion in the plane of their profitability. It also touches on issues of distribution of the revenue, which will undoubtedly affect the system of social relations in all its manifold manifestations. Outside of this context, analysis of the problems of both human capital and capital in general loses all meaning.

To substantiate the ideas which were expressed, an analysis of the major categories of labor economics, including «labor power», «labor potential», «human capital», is presented in the article. It is argued that the central issue of labor potential is the question of the ability to solve the economic problem at a certain level of economic system. In this sense, the labor potential is defined as a generalized description of the society, labor collective and the individual, expressing their ability to solve a wide range of economic problems if the necessary technology, and material and financial resources are available. However, the economic category of «human capital» has a different nature and purpose. It shows the nature and patterns of distribution of the social product between different segments of the population, the status and role of different social strata, the prospects of improving the level and quality of life of workers and their families.

In general, as a result of the investigation, the author concluded that the problem of human capital can be viewed from the perspective of two interrelated planes: investment that reflects the regularities of the formation of an asset, and productive, which contains answers to the question of the consequences of its practical application. Accordingly, a conclusion is formulated that the human capital must be understood as an economic asset that is generated as a result of various investments through purposeful modification of the productive capacity of an individual (society as a whole). It also represents these possibilities in the course of employment which provides some income to participants of the investment and the production processes. Proper application of these economic categories is a prerequisite to identify effective measures to develop the scope of industrial relations.

Keywords: terminology, labor economics, labor potential, human capital, level and quality of life. 